\title{
Future Policies for Distance Education in the Kingdom of Saudi Arabia
}

\author{
Areej ALsaysi \\ Taibah University \\ Saudi Arabia
}

\begin{abstract}
This study aims to analyze the current status of distance higher education in Saudi Arabia in order to identify a justification for the recourse to a virtual university, the appropriateness of the Saudi learning environment for this type of education, and the requirements of a virtual university. It employs a descriptive approach, collecting statistical data from reliable local and international sources, in addition to conducting personal interviews with admissions deans and other university agents who have a direct link to the subject matter. There are two primary reasons for the lack of appropriateness of a virtual university in the Saudi learning environment: the lack of faculty members and technical staff qualified to deal with the technology required for distance education, and the fact that universities are not technically qualified to activate distance learning. This kind of education has a number of requirements incompatible with the Saudi environment, including: a strong Internet technology infrastructure, including maintenance and technical support around the clock, a trained and qualified human infrastructure to manage this type of learning and develop electronic courses, and faculty that have a positive attitudes towards this way of learning and teaching, are able to develop and remotely manage e-learning courses, and respect electronic communication schedules with students.
\end{abstract}

\section{Introduction}

The Virtual University represents the latest version of the idea of distance higher education. It also offers the ability to provide all the same services as a traditional university, while being supported by Internet technology and contact points on the World Wide Web. There is a vast increase in the number of universities and educational institutions that have adopted this type of education and started offering curricula and educational materials online, enabling any student anywhere in the world to attend its programs of study. The United States has more than two thousand institutions of higher education that broadcast at least one of their programs or courses on the Internet. According to the National Center for Education Statics [1], the number of students who are enrolled in online education programs is $5,452,100$.

Michigan Virtual Learning Research Institute is the most recent addition to the Michigan Virtual University organization. It was established in 2012 to expand Michigan's capacity to support new learning models, engage in active research to inform new policies in online and blended learning, and strengthen the state's infrastructures for sharing best practice [2].

The Kingdom of Saudi Arabia (KSA) has some initiatives in this area, and the girl's college agency of the Ministry of Education has already begun an ambitious distance education project that uses a satellite system (VSAT) to remotely teach students in more than 100 girls' colleges throughout the Kingdom [3]. And many higher educational institutions have introduced and are offering eLearning systems as a tool to deliver course content and enhance access to the courses [4].

The Knowledge International University represents the first virtual university in the Kingdom of Saudi Arabia. Its main goal is to bring higher education to people who are unable to enroll in studies programs at conventional universities. But it only provides Bachelor of Arts degrees in Islmic Studies and only thirty students began formal study in the first year [5]. This indicates that the Saudi environment is still not suitable for this type of education, and highlights the need to improve and develop an educational environment that is more compatible.

There does exist an integrated educational system that depends on utilizing modern technologies in the field of e-learning and distance education, which was established in the form of a National Center for elearning and Distance Education. It supports the educational processes of institutions of higher education, without temporal or spatial restrictions. It was established to achieve the Saudi Kingdom's mission to disseminate science and knowledge based on Islamic principles and values, to unite the efforts of different universities, and to build a vision for elearning and distance education that is accessible to all. It aims to both expand and raise the quality of the application of electronic and distance learning in 
higher education, as well as to increase university capacity [6]. As such, the National Center for Distance Education would create the base for building a virtual university in Saudi Arabia.

There are noticeable changes that can be seen in the domain of e-learning, such as the remarkable growth of online courses offered by Deanships and Faculties of Distance Learning at three universities: King Abdulaziz University (KAU) in Jeddah King Saud University (KSA) in Riyadh, and King Faisal University (KFU) in Hofuf [7]. For example, King Abdulaziz University offers students the opportunity to obtain a Bachelor's degree via distance education. The duration of study is four years in the colleges of Arts and Humanities and the Faculty of Economics and Management, and over 6,000 male and female students are enrolled in various distance education programs [8].

In addition to this, years ago, Al-Asmari and Rabb Khan reported that KSA projected [7] US $\$ 125 \mathrm{~m}$ worth of support for the e-learning industry for 2008, to grow at a compound annual rate of $33 \%$ over the following five years, to reach US $\$ 670 \mathrm{~m}$ by 2014. This projection only put more pressure on KSA to meet the higher education requirements of distance education programs.

In addition, distance education in Saudi Arabia lacks a strategic plan for its implementation, which drove the First International Conference of elearning and distance education [9] to initiate a national strategic plan for implementing e-learning and distance education in Saudi Arabian universities through the National Center. As Al-Asmari and Rabb Khan [7] say, e-learning at colleges in KSA lack a unified national e-learning strategy for proper deployment. They also consider the non-accredited status of online courses over the Internet in KSA as the main reason for not taking online courses. This observation is supported by Alshwaier; Youssef and Emam [10] who observe that the Ministry of Higher Education's outdated regulations require students to "present evidence that his/her time was dedicated to studying, on a full-time basis, while residing in the country where the degree was earned" in order to receive that degree from any international university. In 2010, the Distance Learning Regulations in the Higher Education Institutions of KSA approved degrees obtained from these three universities. The list of universities with distance degrees rejected by KSA include MIT, Harvard, and Stanford in the US, and Oxford in the UK. This means that Saudi students cannot qualify with such degrees to get a government job. They cannot pursue graduate-level education in KSA based on these internationally earned degrees.

This reflects the increasing need for new policies around higher education in the Kingdom of Saudi Arabia in ordered to match the efforts that are being made to increase student enrollment in such educational programs. The problems being addressed in this study can be summed up in the following questions:

1. Why resort to a virtual university?

2. How appropriate is the educational environment in Saudi Arabia for this type of education?

3. What are the requirements for establishing a virtual university in the Saudi environment?

The study uses a descriptive approach and statistical data collected from reliable local and international sources, in addition to personal interviews with admission deans and their agents in both male and female Saudi universities who have a direct link to the subject matter. There were 28 individual respondents to the interviews. When we analyze the current status of higher education in Saudi Arabia, we find that there are a number of reasons for considering a virtual university.

\section{The arguments for a virtual university}

There are multiple reasons to establish virtual universities. Among them are:

\subsection{The need for university expansion}

There is an accumulation of high school graduates who can't access universities due to their inability to absorb these growing numbers. The increase in the human fertility rate (2.7), owing to the age distribution of the Saudi population, has led to a higher proportion of university-aged people in Saudi society. Saudi Arabia has one of the highest population growth rates in the world, with an annual rate of $1.8 \%$ for 2015 , significantly higher than the average global rate of $1.1 \%$ [11]. This places enormous pressure on the government to provide basic services, such as education.

Alhabib [12] advocates that absorbing high school graduates is a challenge for higher education institutions in Saudi Arabia, where the average ratio of students of higher education is 2,000 per 100,000 compared to 3,976 and 3,252 for developed and developing countries, respectively. Even though the universities were able to absorb about two-thirds of high school graduates during the Sixth Development Plan, the Seventh Development Plan illustrates that target numbers of male and female students in accordance with the absorptive capacity of higher education institutions would only reach $(37.2 \%)$ of the total number. The challenge of absorbing those graduates remains throughout the Eighth Development Plan also, which indicates that the 
there will be 164,000 new university entrants in the last year of the plan [13].

By following the number of Number of High School Graduates during the period between 2092013 [14-15], one cans see that there is a steadily marked increased showing a jump in the number of high school graduates from 347,100 in 2009 to 403,900 in 2013 - a rise of $14 \%$. It is expected that this increase will arrive at 460,446 if it flows at the same rate. This would require implementing a number of new policies that work to accommodate the increasing number of high school graduates.

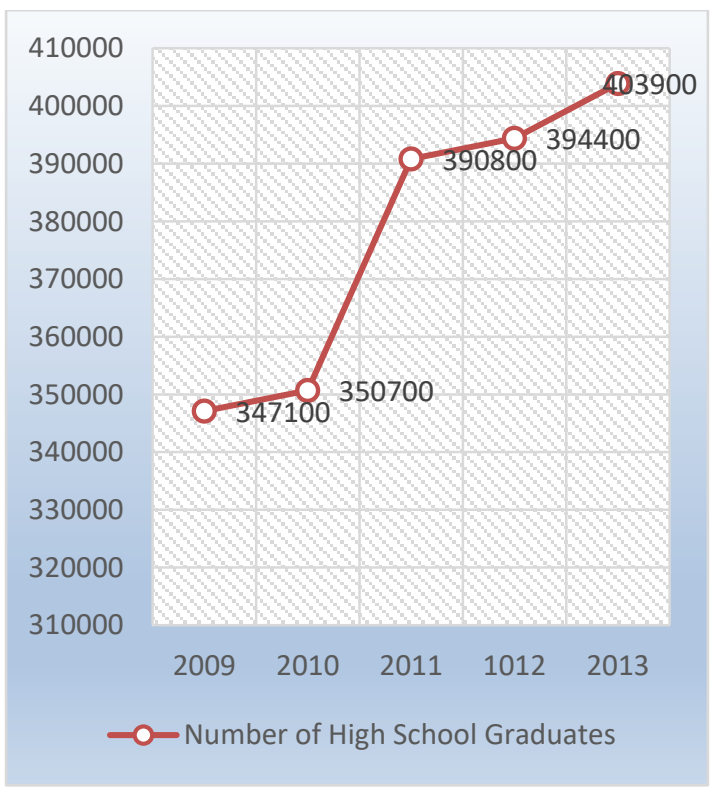

Figure 1. Number of high school graduates

\subsection{Low admissions rate}

Alhabib [12] confirms that the problem of admission started to become clear in 1994, when a number of high school graduates were unable to be absorbed by private universities and institutions of higher education in general. Alsultan [17] emphasizes that the number of students accepted to higher education institutions increases annually, but this increase in admissions is not commensurate with the increase in the number of high school graduates, due to limited resources. Alhafzi [16] points out that the increased number of high school graduates seeking entrance into universities has impacted the quality of education.

Many studies have sought to find solutions to this problem, but the higher education system still suffers from the inability to absorb these increasing numbers, and the problem of acceptance is a growing problem. There are many studies that suggest that this problem will become more serious in the coming years unless real solutions are devised [12-17].

\subsection{The increase in the proportion of students admitted to higher education}

The increase in the numbers of students who were admitted to higher education, as shown in Figure 1, suggests the very real impact of pressures on the absorptive capacity of institutions. This includes the burden on the Ministry of Education with regards to assimilation, acceptance, faculty members, and others in the educational process, calling for the expansion of universities.

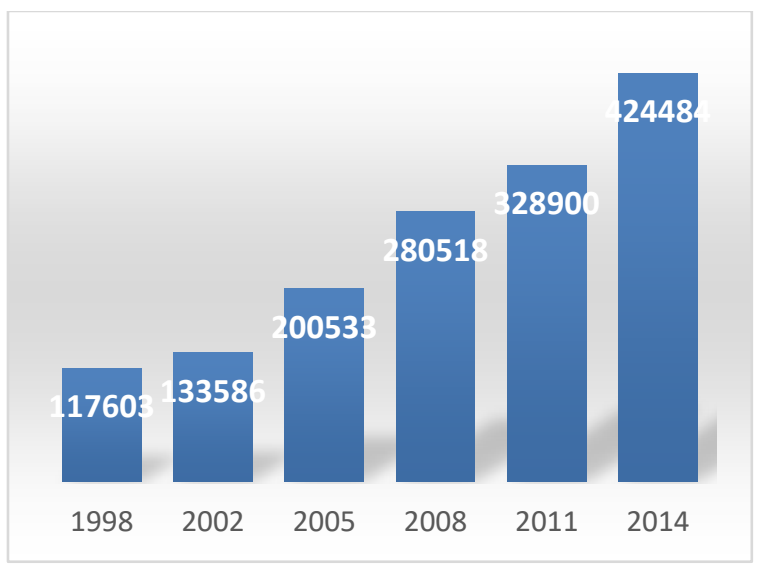

Figure 2. Number of admissions in higher education

The Saudi government has adopted a number of policies to increase the absorption rates of high school graduates in higher education institutions. Among issues these policies address is the expansion of distance education, and the Ministry of Higher Education is moving towards the recognition of distance education and e-learning, both at official local universities and international universities. Distance learning has been introduced in all universities in Saudi Arabia, and a number of Saudi universities and colleges have adopted e-learning practices as part of their curricula.

\subsection{Cost of distance education}

Since distance education has no space boundaries, and is not bound by numbers of staff, its ability to accommodate the growing numbers of students is greater, and it provides more opportunities for special groups, including low income students, residents of remote areas, and females students who are hindered from attending university due to their social conditions. Al-Asmari 
and Rabb Khan [7] stated that the average running expenditure per student enrolled in various distance education programs is very low compared to the cost of regular education. Since distance education can operate with a limited number of employees, money is not spent on infrastructure to accommodate the students, on educational equipment, or on complementary services. Distance education is also not bound to a particular number of full-time teaching staff, as it can benefit from the expertise of specialists in other areas without the need for employing them on a permanent basis.

While the education system in KSA is under stress to provide additional educational opportunities for an increasing population, there is a discrepancy between the growth rate of the existing capacity of Saudi educational institutions and that of enrollment demands. In addition to the rapid expansion of their university system, KSA has also demonstrated a strong commitment to modern education in their hiring of many faculty members from countries such as Egypt, India, Bangladesh, Sudan and Pakistan [7]. KSA's dependence on the government as a primary funding source has placed an extra burden on the government.

This reflects KSA's need for distance learning in order to decrease their higher education budget and meet the requirements of a need for increased university capacity.

\subsection{Staff member shortages}

Saudi universities are suffering from a decrease in the number of faculty members who have proper training. Al-Asmari and Rabb Khan [7] state that there is a considerable shortage of female lecturers in institutions, thousands of students are over-enrolled by these institutions and simply given the course materials and sent home to study on their own, and there are demands for part-time study as well. While distance education is considered an important solution, as mentioned by Alojaiman, Alturise and Goodwin [18], the issue of staff shortages can be reduced significantly by employing an eLearning approach. They assert that the Internet makes it possible to design interactive course material that can then be delivered online to students who are registered in the course.

\section{Distance education policies in Saudi Arabia}

With regards to current policies addressing the increase in student enrollment in higher education institutions, the field study group consisting of 28 admissions deans and their agents at Saudi universities $(n=28)$ have indicated in personal interviews that there are a number of policies that should be applied in Saudi universities to increase the enrollment of students. Specifically, $21.43 \%$ of respondents believe that the expansion of distance education programs can contribute to an increase in student enrollment.

Table 1. The role of distance education policy as viewed by respondents in descending order

\begin{tabular}{||c||l||c||}
\hline \hline Rank & $\begin{array}{l}\text { The role of distance education } \\
\text { policy in raising student } \\
\text { enrollment. }\end{array}$ & Ratio \\
\hline \hline 1 & $\begin{array}{l}\text { It contributes to the increase of } \\
\text { student enrollment in higher } \\
\text { education institutions, as it can } \\
\text { absorb larger numbers of } \\
\text { students. }\end{array}$ & $50 \%$ \\
\hline \hline 2 & $\begin{array}{l}\text { It increases higher education } \\
\text { opportunities for students who } \\
\text { don't meet the admission } \\
\text { requirements (for students who } \\
\text { graduated from high school a } \\
\text { number of years ago, or those } \\
\text { with low grades, etc.). }\end{array}$ & \\
\hline 3 & $\begin{array}{l}\text { It adds flexibility that fits } \\
\text { women's circumstances. }\end{array}$ & $21.43 \%$ \\
\hline \hline 4 & $\begin{array}{l}\text { It contributes to resolving the } \\
\text { problem of understaffed } \\
\text { faculties in some disciplines. }\end{array}$ & $17.86 \%$ \\
\hline \hline 5 & $\begin{array}{l}\text { It is commensurate with art } \\
\text { disciplines. }\end{array}$ & $17.86 \%$ \\
\hline \hline 6 & $\begin{array}{l}\text { It is currently used for associate } \\
\text { students. }\end{array}$ & $14.29 \%$ \\
\hline 7 & $\begin{array}{l}\text { It saves a large portion of the } \\
\text { budget. }\end{array}$ & $14.29 \%$ \\
\hline \hline & \multicolumn{2}{|c||}{} \\
\hline \hline
\end{tabular}

Table 1 shows the respondents' support of distance education policies. They considered it one of the most important means to help raise student enrollment, for many reasons: (1) Its absorption capacity for larger numbers of students without the need for additional buildings and equipment (50\% of the respondents agreed); and (2) Its ability to increase higher education opportunities for students who do not meet admission requirements (e.g. high fees, time limit for the number of years between graduation from high school and application to higher education institutions, and dropout students), (21.43\% of the respondents agreed); (3) It offers a certain flexibility that fits the circumstances of women, as it allows students living in remote places and, housewives, and working women to receive their education without the need to transport or move to the place of learning $(21.43 \%$ of the respondents agreed). $17.86 \%$ of the respondents agreed that 
distance education contributes to resolving the problem of low numbers of faculty members in certain disciplines, and is commensurate with art disciplines that do not require a lot of interaction between teachers and students. $14.29 \%$ of respondents agreed that this type of education currently used for associate students, and can save a large portion of budget.

Women's colleges in particular have benefited from this type of education, as 12 colleges are currently teaching the same program through distance education, which has helped reduce the number of faculty members, thus solving the problem in some colleges that suffer from a shortage of faculty members in certain disciplines. Despite their advocacy for distance education, study participants felt that applying a distance education policy in Saudi Arabia would still be associated with some negative aspects, as reflected in Table 2.

Table 2. Negative aspects of distance education policy as viewed by respondents in descending order

\begin{tabular}{|c||c||c||}
\hline Rank & $\begin{array}{l}\text { Cons of distance education policy } \\
\text { as viewed by the respondents }\end{array}$ & ratio \\
\hline \hline 1 & $\begin{array}{l}\text { Lack of qualified faculty } \\
\text { members and technical staff to } \\
\text { deal with the technology required } \\
\text { for distance education }\end{array}$ & $42.86 \%$ \\
\hline 2 & $\begin{array}{l}\text { It can't be considered as a basis } \\
\text { for granting a university degree, } \\
\text { but is considered complementary } \\
\text { to the educational process }\end{array}$ & $28.57 \%$ \\
\hline 3 & $\begin{array}{l}\text { Universities are not technically } \\
\text { qualified to deal with distance } \\
\text { education }\end{array}$ & $25.00 \%$ \\
\hline 4 & $\begin{array}{l}\text { The job market does not accept } \\
\text { distance education graduates }\end{array}$ & $17.86 \%$ \\
\hline 5 & $\begin{array}{l}\text { Distance education impedes } \\
\text { constructive interaction between } \\
\text { teachers and students }\end{array}$ & $14.29 \%$ \\
\hline 6 & $\begin{array}{l}\text { The lack of disciplines that suit } \\
\text { the wishes of the students }\end{array}$ & $3.57 \%$ \\
\hline 7 & $\begin{array}{l}\text { The Ministry of Higher Education } \\
\text { is still in the early stages of } \\
\text { developing a distance education } \\
\text { program }\end{array}$ & $3.57 \%$ \\
\hline \hline
\end{tabular}

When we analyzed the responses of the study participants with regard to the negative aspects of a distance education policy (as shown in Table 2), we found that $42.86 \%$ believe that there is a lack of qualified faculty members and technical staff to deal with the technology required for distance education, and $28.57 \%$ believe it cannot be considered as a basis for granting a university degree, but can only be complementary to the educational process. $25 \%$ reported that universities are not technically qualified to activate distance education, while $17.86 \%$ agreed on the non-acceptance of the job market with regards to distance education graduates. $14.29 \%$ believed that distance education hinders constructive interactions between teachers and students, and a further portion of $3.57 \%$ agreed that there was a shortage of disciplines offered that suit distance education, and that the Ministry of Higher Education is still in the early stages of developing such programs.

In order to address the disadvantages of the current policy for distance education, there is a need to expand the activation of distance education in Saudi Arabia. Saudi Arabia is vast, and distance education can provide opportunities that cope with distance and enable everyone to access higher education. This is consistent with the need of Saudi society to establish an open university that grants high schools graduates acceptance opportunities commensurate with the increase in the population, and at the same time reduces the pressures on traditional universities. The interview respondents suggested a number of policies to increase the role of distance education in raising higher education enrollment in the Saudi Kingdom, as shown in Table 3. The most important proposals to increase the role of distance education and improve admissions rates to institutions of higher education, are reflected in these results:

(1) $39.29 \%$ of respondents supported the option of offering developmental training for faculty members and technical staff to improve their capacity to deal with the technology associated with distance education. Along these lines, Afifi [19] concluded that care must be taken to train staff members on distance education. The recommendations of the First International Conference on E-learning and Distance Education [9] also recommended the provision of sufficient training programs for I distance education faculty in order to ensure that they receive the skills necessary to deal efficiently with programs.

(2) $28.57 \%$ were advocates of providing universities with the appropriate infrastructure for distance education, which in turn would contribute to increasing the role of these programs in raising student enrollment at said universities. The First International Conference of E-learning and Distance Education [9] list the establishment of infrastructure among their recommendations. They describe it as including the provision of appropriate networking infrastructure as well as the construction of electronic and virtual classrooms equipped with the latest technologies. 
Table 3. Policies suggested by respondents to improve the role of distance education

\begin{tabular}{|c|c|c|}
\hline Rank & $\begin{array}{l}\text { Policies suggested to improve the } \\
\text { role of distance education }\end{array}$ & ratio \\
\hline 1 & $\begin{array}{l}\text { Organize developmental } \\
\text { workshops for faculty members } \\
\text { and technical cadres to improve } \\
\text { their ability to deal with distance } \\
\text { education technology. }\end{array}$ & $39.29 \%$ \\
\hline 2 & $\begin{array}{l}\text { Provide the appropriate } \\
\text { infrastructure for universities to } \\
\text { handle distance education. }\end{array}$ & $28.57 \%$ \\
\hline 3 & $\begin{array}{l}\text { Support the application of } \\
\text { distance education in girls' } \\
\text { colleges. }\end{array}$ & $21.43 \%$ \\
\hline 4 & $\begin{array}{l}\text { Transfer associate students into } \\
\text { distance learning programs. }\end{array}$ & $17.86 \%$ \\
\hline 5 & $\begin{array}{l}\text { Apply distance education in arts } \\
\text { disciplines. }\end{array}$ & $10.71 \%$ \\
\hline 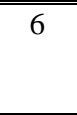 & $\begin{array}{l}\text { Trust distance education and } \\
\text { recognize the degrees as } \\
\text { qualifying students to work. }\end{array}$ & $10.71 \%$ \\
\hline 7 & $\begin{array}{l}\text { Find a center for distance } \\
\text { education in universities that } \\
\text { offers standardized scientific } \\
\text { materials. }\end{array}$ & $7.14 \%$ \\
\hline 8 & $\begin{array}{l}\text { Provide more disciplines that are } \\
\text { suitable to student's wishes }\end{array}$ & $3.57 \%$ \\
\hline 9 & $\begin{array}{l}\text { Support distance } \\
\text { develop education and } \\
\text { mechanisms. }\end{array}$ & $3.57 \%$ \\
\hline
\end{tabular}

Al-Asmari and Rabb Khan [7] assert that the government needs to invest in networking infrastructure to provide constant and stable connections, which are the backbone of e-learning, but that this does represent a significant financial burden. A large investment in KSA's media infrastructure is needed.

(3) $21.43 \%$ of respondents thought it was important to support the application of distance education in girls' colleges due to high attendance and few resources.

(4) $17.86 \%$ agreed on the importance of transferring associate students to distance education programs.

(5) $10.71 \%$ advocated for the application of distance learning in arts disciplines, as these disciplines do not require significant interaction between students and teachers, and the labour market has no need for such disciplines. So instead of terminating arts disciplines in universities, they could be transferred to an institution for distance education.

(6) $10.71 \%$ agreed that distance education needs to be trusted and recognized as a source of degrees that qualify students for work. Although the majority of world nations have recognized this type of education for many years - for example, since 1993 in Canada and Singapore, and since 1996 in Korea - Saudi Arabia has not yet recognized it, which makes students reluctant to try it [20].

(7) $7.14 \%$ agreed with the suggestion of finding a center for distance education in universities that offers standardized scientific material.

(8) $3.57 \%$ advocated for the provision of more disciplines that are more commensurate with student's wishes.

(9) $3.57 \%$ think that the Ministry of Higher Education should support distance education and develop its mechanisms, since its application will increase the role of distance education in raising higher education enrollment.

This analysis shows that the most important policies that would contribute to improving the role of distance education and increasing enrollment levels are the expansion of technological networks, and the creation of a virtual university. Despite these proposals, the Saudi educational environment is still behind when it comes to the creation of a viable distance education program.

\section{Requirements for the success of distance education}

Distance education literature indicates that its success requires - among many other requirements a change of the internal and external environments of universities so as to redefine their functions and methods. Remote e-learning does not just place traditional lectures on the web or produce curricula on CDs and multimedia materials. Instead, universities have to address important issues such as new types of knowledge, free themselves of prevailing academic traditions, and address the urgent need for cooperation, partnership, and networking. This kind of education in the Saudi environment has many requirements, including:

- Strong Information Technology infrastructure, including maintenance and technical support around the clock.

- Trained and qualified human support to manage this type of learning, and to develop e-learning courses.

- Faculty who have a positive attitude towards this type of learning and teaching, are able to develop and manage remote e-learning courses, and respect the electronic communication schedules with their students, especially with regards to immediate or synchronous communication on websites.

- Students who are serious about academic achievement, have a high degree of commitment, motivation and determination to learn remotely, are disciplined and independent, have the ability to 
manage their time, possess technical skills, and have access to technical resources.

- Availability of appropriate e-learning study tools for students. For example, recipients must have a computer equipped with a modem and multimedia equipment, and have access to the Internet, an email account, and the minimal technical knowledge needed to use a computer.

- Flexible management systems and institutional commitment.

- An integrated learning environment to support student services.

- Policies, admissions, and graduation standards equivalent to those of traditional universities.

- Quality standards for remote e-learning systems.

- A strong infrastructure of modern communication networks, Internet research and training centers. The Kingdom of Saudi Arabia must build a base for the provision and exchange of information between Arab countries, to enable them to make the right decisions about higher education.

- The involvement of research and study centers in the information industry.

- The adoption of the virtual university project by a specialized company that provides it with a server and a course-management program with all the necessary technical tools.

- The development of a practical and feasible strategic plan to create a virtual university.

- The employment of a team of highly qualified people to follow up on the project and overcome obstacles to completing it.

- Communication with other Arab universities. Students who are interested in completing their graduation projects in the field of educational technology could possibly help out in exchange for a certificate of experience and financial rewards.

\section{Conclusion}

This study resulted in a number of conclusions: (1) There are many reasons that a virtual university is needed, such as the desirability of expansion in universities, low admission rates, an increase of the proportion of students who were not admitted to higher education. (2) The appropriateness of the Saudi learning environment for a virtual university is weak for many reasons, including: the lack of faculty members and technical staff qualified to deal with the technology required for distance education, the inability to consider distance education as a basis for granting a university degree, the fact that universities are not technically qualified or equipped to activate distance learning, and non-acceptance into the job market for distance education graduates. (3) This kind of education has some requirements in the
Saudi environment, such as: (a) a strong IT infrastructure, including maintenance and technical support around the clock; (b) a trained and qualified human support infrastructure to manage this type of learning; and (c) faculty that have a positive attitude towards this type of learning and teaching.

\section{References}

[1] National Centre for Education Statistics, (2013). Number and Percentage of Student Enrolled at Title IV Institution. N.p. [Online]. Available: 11 June 2016. <http://nces.ed.gov/ipead/glossary>.

[2] S. Lafayette, "Michigan Virtual University: Providing Online Learning Opportunities", Distance Learning, vol. 12, no.2, 2015, PP 45-52.

[3] B. A. Alsaleh, (2010). E- Distance education in Saudi Arabia universities: improve the education or educate the public? [Online]. Available:

http://www.almarefh.org/news.php?action=show\&id=322. (Access date:26 march 2010)

[4] S. Alkhalaf, S. Drew, R. AlGhamdi and O. Alfarraj, "E-Learning system on higher education institutions in KSA: attitudes and perceptions of faculty members", Social and Behavioral Sciences, vol.47, 2012, pp1199 1205.

[5] Knowledge International University, (2015) KIU Vision \& Mission [Online]. http://kiu.org/website.

[6] ministry of higher education, (2016). National Center for e-learning and Distance Education [Online]. Available: https://www.mohe.gov.sa/en/aboutus/Institutions/Pages/Di stance-education.aspx

[7] A.M. Al-Asmari and M.S. Rabb Khan, "E-learning in Saudi Arabia: Past, present and future", Near and Middle Eastern Journal of Research in Education, VOL.2, 2014, [Online]. Available: http://dx.doi.org/10.5339/nmejre. 2014.2

[8] King Abdul Aziz University, (2016). Deanship of Distance Learning [Online]. Available:

http://www.kau.edu.sa/home_ENGLISH.aspx. (Access date: 11 march 2016).

[9] Ministry of Higher Education, (2009). First International Conference on E-learning and Distance Education, Riyadh, 19-21 Rabi' I, 1430 [Online]. Available: http://www.eli.elc.edu.sa/2009. (Access date: 26 march 2010)

[10] A. Alshwaier, A. Youssef and A. Emam, (2012, January), a New Trend for E-learning in KSA Using Educational Couds. Advanced Computing: An International Journal (ACIJ), 3(1), 81-97. [Online]. http://airccse.org/journal/acij/papers/0112acij07.pdf 
[11] Human Development Report, (2015), UNDP, New York [Online]. Available: http://hdr.undp.org/en/2015report. (Access date: 20 February 2016).

[12] F. I. Alhabib, (2006). The future of higher education in Saudi Arabia: a proposed strategy, The conference of exploring the future of education, the Arab Organization for Administrative Development, 17-21 April 2006, Egypt.

[13] Ministry of Economy and Planning. Department of Statistics. (2004). Statistical Yearbook, 1424/1425.

[14] Ministry of Economy and Planning (2005)- (2014) Achievements of Development Plans- Facts and Figures (1427-1435).

[15] Ministry of Higher Education (1998)- (2014), Higher Education Statistics in Saudi Arabia.

[16] Y. S. Alhafzil, "Higher education in Saudi Arabia (Future vision)", Journal of Faculty of Education, vol. 45, January 2004.

[17] K. S. Alsultan, (2001). "Future Educational policy of higher education", paper submitted to: the symposium on "visions of the future of the Saudi economy till 1440 "[Online]. Available: www.planning.gov.sa.(Access date: 12 December 2008)

[18] B. Alojaiman, F. Alturise, and R. Goodwin, "Towards a Dynamic e-Learning Adaptation Framework for Saudi Arabian Higher Education Institutions: A Literature Review", nternational Journal of Advanced Research in Computer Science \& Technology, vol. 2(3), 2014, pp 182189. [Online]. Available: https://www.hesa.ac.uk/sfr224 (access_July 19, 2016).

[19] M. Y. AH.Afifi, (2007). The reality and the future of distance education in Saudi Arabia (field study), Faculty of Dawa and Fundamentals of Religion - the Islamic University. Medina.

[20] A.H. Shawashira, (2006). Open University studies and adult education, Conference on the role of Arab Non Profit Organizations in achieving the Millennium Development Goals in the Arab States: partnership to build the future. Kuwait in 18-20 December 2006. 